\title{
INDUKSI PERAKARAN BIBIT TANAMAN \\ NANAS BOGOR (Ananas comusus L. Merr) \\ ASAL STEK DAUN MAHKOTA BUAH
}

\author{
Karmanah ${ }^{1 *}$ dan Siswanti ${ }^{2}$ \\ 1)Program Studi Agroteknologi, 1,2 Faperta Universitas Nusa Bangsa Bogor \\ Jl. KH Sholeh Iskandar Km. 4 Cimanggu, Bogor \\ 1)Email : karmanahs@yahoo.com
}

\section{ABSTRACT
Rooting Induction of Seedling Plants of Bogor Pineapple (Ananas comusus L. Merr) from leaf cuttings of the crown fruit

This research aim to deternime the effect of the wee of Indole Bunric Actd (IRA) in the axpropriate dase

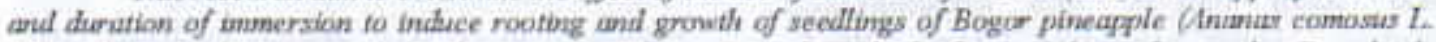
Merr) from leaf cuttings of the fruit cronn. The statistical method of research ased war the Completely Randomized Design with two factorz. The forst factor was IRA dose treatment $L$ e $=0 \mathrm{mg} / \mathrm{t}, 50 \mathrm{mg} / \mathrm{l}, 100 \mathrm{mg} / \mathrm{l}$ and $200 \mathrm{mg} / \mathrm{l}$ The secund factor was the length of immersion tume i. e : 5 minutes, 10 minates and 15 minutes, The restls showed that use of IBA dose up to $50 \mathrm{mg} / \mathrm{I}(\mathrm{AL})$ significantly increased the number of shoots, thoot height and number of leaves. While soatung time for 5 mimutes (WI) significantly ancreased of shoot height and ramber of leaves. The interaction benveen the use of $I \mathrm{Bt}$ dase $50 \mathrm{mg} / \mathrm{l}$ and the length of rime soaking 5 minutes (A2WI) was the best treatment interaction by providing a agyificant effect on all the parameters of the gowth of shoots and roots of secellings Bogar ptneapple from leaf cuttings of the fruit cronm.

Key word: Bogor paneapple, Indole Butyric Acid (IR-4), Soaking Time, Leaf Cuttugs, Roots

\section{ABSTRAK}

Tuium peneitian ini adalah umtnk menentukan pengaruh Indole Butyric Acid (IBA) dengan herbagai dosis dan lama pencelupan untuk menginduksi perakaran dart pertumbuhan bibit tanaman nanas Bogor (Ananas comarus L. Merr) asal stek dam mahkota buah Metode statistik yang digunakan dalam penelitian adalah Rancangan Acak Lengkap (RAL) dengan 2 faktor. Faktor pertama adalah dosis IBA yaitu : 0 mg/, 50 mg/, $100 \mathrm{mg}$ 1, $200 \mathrm{mg}$. Faltor kedua adalah lam waktu peneclupan yuitu : 5 menit, 10 menit dan 15 menit. Hasil menuniukan bahwa peragumaan IBA dengan dosis 50 mgl secura myuta meninglkatikan jumlah akar dan jumlah dum, sementarn lama walks pencelupan 5 ment (WI) secara nyata menungkutaun tinggi akar dun jumiah daun Interaksi antara penggumaan desis IBA $50 \mathrm{mg} / \mathrm{dan}$ lama pencelupan 5 menit ( dan memberkan pengarnh pada pertumbuhan akar duri bitit tanuman nanas Bogor asal stek daum mahkota buah.

Kata kanci : nanas Bogor, indole Butyric Acid (IBA), waktu perendaman, stek deun, alkar

\section{PENDAHULUAN}

Nanas (Ananas comosus L. Merr) varietas Mahkota Bogor merupakan nanas jenis Queen. Umumnya perbanyakan bibit tanaman nanas dilakukan dengan cara menanam mahkota buah secara utuh, eara lain yang dapat dilakukan adalah dengan menanam stek daun yang berasal dari mahkota buah. Perbanyakan dengan cara stek daun dari mahkota buah ini dapat menghasilkan bibit yang jumlahnya lebih banyak, karena dari satu mahkota buah bisa dihasilkan $10-20$ stek daun.

Berdasarkan hasil penelitian Setiawan, et al (2010), bibit asal stck daun mahkota buah yang ditanam pada beberapa kombinasi media dihasilkan bibit yang jumlahnya lebih banyak, dengan pertumbuhan yang lebih cepat dan seragam, akan tetapi perakaran yang dihasilkan relatif sedikit. Oleh karena itu untuk meningkatkan jumlah perakaran perlu dilakukan induksi perakaran' bibit tanaman nanas. 
Menurut Wattimena (1987), salah satu zat pengatur tumbuh yang digunakan untuk mendorong pembentukkan akar pada stek adalah kelompok auksin yaitu Indole Butyric Aczd (IBA). Hasil penelitian pemberian ZPT IBA pada eksplan nanas (Anaras comusus) "Variegatus" yang diperbanyak secara in vitro, menunjukkan bahwa penambahan IBA $2,5 \mathrm{mg} / 1$ menghasilkan pertumbuhan akar terbaik (Sukawan, 2000). Hasil Penelitian Karmanah (1996), penggunaan ZPT IBA dengan konsentrasi $200 \mathrm{ppm}$ pada tanaman kelapa dapat merangsang pertumbuhan akar lebih banyak jika dibandingkan kontrol Hasil penclitian Utami (2002), pemberian IBA $750 \mathrm{ppm}$ dengan metode perendaman pada stek tanaman jati mampu meningkatkan persentase hidup dan berakar stek pucuk jati sebesar $100 \%$ dan memberikan kemampuan stek hidup lebih baik dibandingan dosis $500 \mathrm{ppm}$ dan 0 ppm (kontrol). Dalam penelitiaan lainnya, penggunaan ZPT IBA pada Shorea balangeran Korth pada taraf dosis $25 \mathrm{ppm}$ dengan metode perendaman selama 15 menit merupakan konsentrasi yang optimum dan menghasilkan panjang akar terbaik dengan panjang rata-rata $14,43 \mathrm{~cm}$ (Budiman, 2000).

Dalam penelitian ini induksi perakaran bibit tanaman nanas asal stek daun mahkota buah dilakukan dengan penggunaan Zat Pengatur Tumbuh Indole Butyric Acid (ZPT IBA). Namun belum ditemukan dosis ZPT IBA yang tepat dan lamanya waktu perendaman untuk menginduksi perakaran bibit nanas tersebut, oleh karena itu perlu dikaji bagaimana pengaruh dosis ZPT IBA dan waktu perendaman yang tepat untuk menghasilkan perakaran dan pertumbuhan bibit tanaman nanas yang optimal.

Penelitian ini bertujuan untuk mengetahui pengaruh penggunaan Zat Pengatur Tumbuh Indole Butyric Actd (ZPT IBA) dengan dosis yang tepat dan lamanya waktu perendaman untuk menginduksi perakaran dan pertumbuhan bibit tanaman nanas Bogor (Ananas comosus L. Merr) asal stek daun mahkota buah.

\section{METODE}

\section{Bahan Tanaman}

Bahan yang digunakan adalah Mahkota buah nanas Bogor yang diperoleh dari Kelompok Tani Binaan PKBT IPB di daerah Ciapus Bogor. Mahkota buah nanas diambil dari tanaman nanas siap panen (umur 9 bulan).

\section{Metode Penelitian}

Penelitian dilakukan di Rumah Kaca Universitas Nusa Bangsa yang berlokasi di J. KH. Sholeh Iskandar Km. 4, Cimanggu Bogor. Raneangan percobaan menggunakan rancangan 2 faktorial yang disusun dalam rancangan acak lengkap (RAL). Faktor pertama adalah penggunaan ZPT IBA dengan 4 taraf dosis perlakuan yaitu : A1 : $0 \mathrm{mg} / \mathrm{l}$ (Tanpa IBA), A2 : $50 \mathrm{mg} /$, A3 : $100 \mathrm{mg} /$, A4 : $200 \mathrm{mg} /$. Faktor kedua adalah Lamanya waktu perendaman terdiri dari 3 perlakuan yaitu : W1 $=5$ menit, $W 2=10$ menit, $W 3=15$ menit. Dengan demikian didapatkan 12 kombinasi perlakuan dengan jumlah ulangan sebanyak 3 kali. Pada setiap kombinasi terdiri atas 6 tanaman sehingga jumlah semua tanaman pengamatan berjumlah 216 bibit tanaman.

Media tanam yang digunakan adalah kombinasi media tanah pasir dengan perbandingan 1: 1 yang ditambah dengan pupuk kandang sapi sebanyak 800 g per polibag (Setiawan, et al , 2010). Setelah media dan pupuk diaduk sampai homogen, kcmudian dimasukkan dalam polibag dan media disiram untuk menjaga kelembaban.

Penyetekkan Mahkota Buah Nanas dilakukan dengan cara memotong dasar daun sampai mengenai jaringan meristem pada kulit batang daun. Pemotongan dengan menggunakan pisau yang bersih dan tidak berkarat, untuk menghindari infeksi pada hasil penyetekkan tanaman. Selanjutnya stek dicelupkan dalam larutan fungisida untuk mencegah infeksi dan membusuknya stek daun karena milkroba.

Perlakuan pemberian ZPT IBA, dilakukan dengan eara terlebih dahulu 
melarutkan IBA ke dalam 1 liter air sesuai dengan taraf dosis IBA yang ditentukan. Kemudian stek daun direndam dalam larutan IBA sesuai dengan perlakuan dosis IBA dengan lamanya waktn perendaman yang berbeda. Stek daun yang sudah diberi perlakukan IBA, kemudian ditanam pada media yang telah disediakan pada kedalaman $2-3 \mathrm{~cm}$ dengan jarak $5 \mathrm{~cm}$ antar tanaman. Jumlah bibit yang ditanam adalah 6 bibit per polybag.

\section{Pengamatan}

Pengamatan dilakukan sejak tanaman tumbuh sampai dengan bibit berumur 12 minggu setelah tanam (mst). Variabel yang diamati meliputi

a. Jumlah Tunas, dilakukan dengan menghitung jumlah mata tunas yang tumbuh pada masing - masing tanaman pada setiap perlakuan.

b. Jumlah Daun, dihitung setelah tamaman mulai tumbuh, dengan kriteria daun sudah terbuka sempuma.

c. Tinggi Tanaman, diukur dengan cara mengukur dimulai dari leher tanaman sampai pada ujung daun tanaman yang tertinggi.

d. Sistem Perakaran yang diamati meliputi panjang akar dan jumlah akar yang diamati pada akhir pengamatan. Panjang akar diukur dengan menjumlahkan panjang akar dari setiap sampel bibit. Sedangkan jumlah akar dihitung banyaknya akar dari setiap sampel bibit.

Analisis Data dilakukan dengan sidik ragam (ANALISIS OF VARIAN) pada tingkat kesalahan 5\%. Jika terdapat perlakuan yang berbeda nyata akan dilakukan uji lanjut dengan uji Duncan.

\section{HASIL}

\section{A. Jumlah Tunas}

Hasil Analisis sidik ragam (ANOVA), perlakuan ZPT IBA berpengaruh nyata terhadap jumlah tunas pada taraf alpha $5 \%(\mathrm{P}=0.000)$, sedangkan waktu perendaman (W) tidak berpengaruh nyata terhadap jumlah tunas pada taraf alpha $5 \%(\mathrm{P}=0.061)$. Interaksi faktor antara perlakuan ZPT IBA dan waktu perendaman berpengaruh yang nyata terhadap jumlah tunas pada taraf alpha $5 \%(\mathrm{P}=0.000)$.

Hasil uji lanjut pengaruh perlakuan ZPT IBA terhadap jumlah tunas, menunjukkan bahwa perlakuan Z.PT IB A 0 $\mathrm{mg} /$ (A1), $50 \mathrm{mg} / \mathrm{A}$ (A) dan $100 \mathrm{mg} /$ (A3) memberikan pengaruh yang tidak berbeda nyata pada taraf alpha $5 \%$. Ratarata jumlah tunas yang dihasilkan dari masing - masing perlakuan yaitu 1.963 (A1), 1.759 (A2) dan 1.870 (A3), sedangkan semakin tinggi dosis IBA yang digunakan $200 \mathrm{mg} / 1$ (A4) menghasilkan jumlah tunas yang lebih sedikit yaitu 0.833 (Tabel 1).

Untuk interaksi perlakuan ZPT IBA dan waktu perendaman menunjukkan bahwa perlakuan ZPT IBA $50 \mathrm{mg} / \mathrm{l}$ dan waktu perendaman 5 menit (A2W1) memberikan respon pertumbuhan jumlah tunas yang paling baik yaitu sebesar 2,667 (Tabel 2).

Secara visual umumnya tunas yang tumbuh baru terlihat seperti mata tumas yang mulai membesar, berwama putih kehijauan, kemudian tunas membesar dan berkembang menjadi tanaman. Perkembangan pertumbuhan tunas dapat dilihat pada Gambar 1.

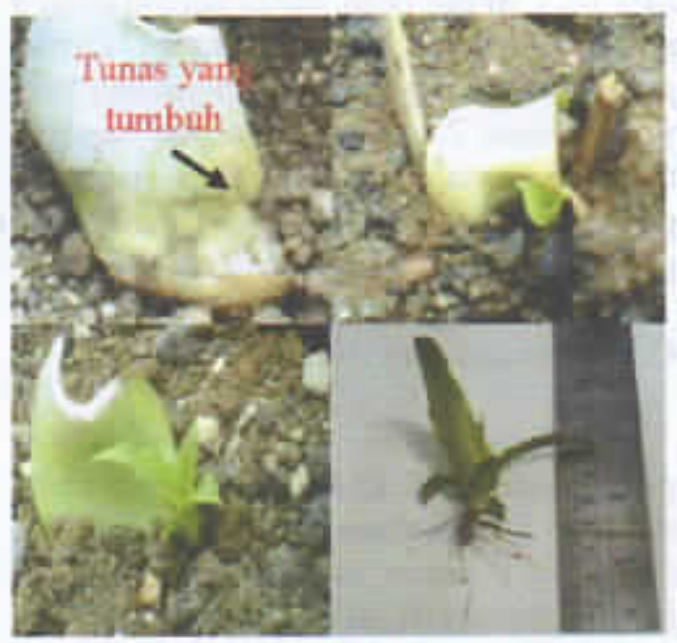

Gambar 1. Pertumbuhan Tunas dari Stek Daun Mahkota Buah 


\section{B. Tinggi Tanaman (Tinggi Tunas)}

Analisa sidik ragam (ANOVA), menunjukkan penggunaan ZPT IBA berpengaruh nyata terhadap tinggi tunas pada taraf alpha $5 \%(\mathrm{P}=0.008)$, selain itu waktu perendaman juga berpengaruh nyata terhadap tinggi tunas pada taraf alpha $5 \%$ $(\mathrm{P}=0.008)$. Interaksi perlakuan ZPT IBA dan waktu perendaman memberikan pengaruh yang berbeda nyata terhadap tinggi tunas pada taraf alpha $5 \%(\mathrm{P}=$ 0.000 ).

Berdasarkan uji lanjut dengan Duncan terhadap penggunaan ZPT IBA. menunjukkan bahwa periakuan ZPT IBA 0 mg/ (Al) memberikan respon pertumbuhan tinggi tunas yang paling baik yaitu sebesar $1,659 \mathrm{~cm}$, walaupun hasilnya tidak berbeda nyata dengan perlakuan dosis ZPT IBA $50 \mathrm{mg} /($ A2) (Tabel 1). Hasil uji Duncan pengaruh waktu perendaman terhadap tinggi tunas menunjukkan bahwa waktu perendaman yang lebih cepat yaitu 5 menit (W1) memberikan tinggi tunas yang paling baik yaitu scbesar $1.618 \mathrm{~cm}$ (Tabel 1). Sedangkan semakin lama waktu perendaman mengakibatkan rata-rata pertumbuhan tinggi tunas yang lebih rendah.

Untuk interaksi perlakuan ZPT IBA dan waktu perendaman, hasil uji Duncan menunjukkan bahwa perlakuan ZPT IBA $50 \mathrm{mg} / \mathrm{d}$ dan waktu perendaman 5 menit (A2W1) memberikan respon pertumbuhan tinggi tunas yang paling baik yaitu sebesar $2.664 \mathrm{~cm}$, walaupun hasilnya tidak berbeda nyata dengan interaksi perlakuan ZPT IBA $200 \mathrm{mg} / \mathrm{d}$ dan waktu perendaman 10 menit (A4W2) (Tabel 2).

\section{Jumlah Daun}

Berdasarkan hasil ANOVA, penggunaan ZPT IBA berpengaruh nyata terhadap jumlah daun pada taraf alpha $5 \%$ $(\mathrm{P}=0.033)$, selain itu waktu perendaman juga berpengaruh nyata terhadap jumlah daun pada taraf alpha $5 \%(\mathrm{P}=0.001)$. Interaksi faktor antara perlakuan ZPT IBA dan waktu perendaman berpengaruh nyata terhadap jumlah daun pada taraf alpha $5 \%$ $(\mathrm{P}=0.000)$.

Berdasarkan uji lanjut dengan Duncan terhadap masing - masing faktor menunjukkan bahwa perlakuan ZPT IBA 0 mg/ (AI) memberikan respon pertumbuhan jumlah daun yang paling baik yaitu 2.665 (Tabel 1). Sedangkan hasil uji lanjut terhadap waktu perendaman menunjukkan bahwa waktu perendaman yang lebih eepat yaitu 5 menit (W1) memberikan respon pertumbuhan jumlah daun yang paling baik yaitu 2.483 (Tabel $1)$.

Hasil uji Duncan untuk interaksi perlakuan ZPT IBA dan waktu perendaman menunjukkan bahwa perlakuan ZPT IBA $200 \mathrm{mg} / \mathrm{l}$ dan waktu perendaman 10 menit (A4W2) memberikan respon pertumbuhan jumlah daun yang paling baik yaitu sebesar 3.561 , tetapi hasilnya tidak berbeda nyata dengan perlakuan ZPT IBA $0 \mathrm{mg} / 1$ dan waktu perendaman 5 menit (AIWI) serta perlakuan ZPT IBA $50 \mathrm{mg} / \mathrm{l}$ dan waktu perendaman 5 menit (A2W1) (Tabel 2).

Selain pengamatan terhadap pertumbuhan tunas, tinggi tunas dan jumlah daun, dilakukan pula pengamatan secara visualisasi terhadap pertumbuhan stek daun. Hasil pengamatan menunjukkan bahwa sekitar $10 \%$ stek daun mahkota buah nanas mengalami pembusukan (Gambar 2) dengan ciri-ciri :

1. Pembusukan pada jaringan meristem dan jika ditekan mengeluarkan cairan.

2. Gejala pada daun yaitu daun yang awalnya hijau, berubah warna menjadi kuning kecoklatan dan membusuk. Akibatnya stek tidak berkembang bahkan mengalami kematian.

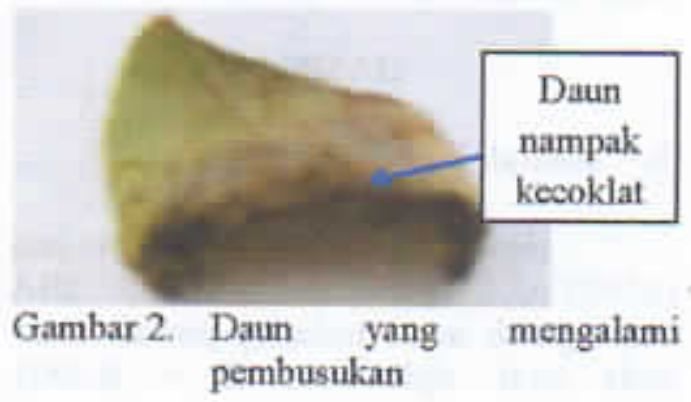




\section{Sistem perakaran}

Berdasarkan hasil ANOVA, baik perlakuan ZPT IBA, waktu perendaman maupun interaksinya tidak berpengaruh nyata terhadap jumlah akar. Namun berdasarkan hasil pengamatan menunjukkan bahwa interaksi perlakuan ZPT IBA $50 \mathrm{mg} /$ dan lamanya waktu perendaman 5 menit (A2W1) menghasilkan rata - rata jumlah akar yang paling banyak yaitu 7,7 buah (Gambar 3 ).

Pada pertambahan panjang akar. berdasarkan hasil ANOVA, penggunaan ZPT IBA tidak berpenganuh nyata terhadap panjang akar pada taraf alpha $5 \%(\mathrm{P}=$ 0.533 ), selain itu waktu perendaman juga tidak berpengaruh nyata terhadap panjang akar pada taraf alpha $5 \%(\mathrm{P}=0.145)$. Interaksi faktor antara penggunaan ZPT IBA dan waktu perendaman mempunyai pengaruh yang nyata terhadap panjang akar pada taraf alpha $5 \%(\mathrm{P}=0.030)$.
Berdasarkan uji Duncan diketahui bahwa interaksi perlakuan dosis ZPT IBA $50 \mathrm{mg} / 1$ dan waktu perendaman selama 5 menit (A2W1) memberikan pengaruh yang paling baik terhadap pertumbuhan panjang akar jika dibandingkan dengan interaksi perlakuan lainnya, yaitu menghasilkan rata-rata panjang akar sebesar $18.967 \mathrm{~cm}$ (Tabel 2). Sedangkan tanpa perlakuan ZPT IBA dan semakin tinggi dosis IBA serta semakin lama waktu perendaman mengakibatkan penurunan jumlah akar bahkan menyebabkan stek tidak berakar, sebagaimana terlihat pada perlakuan ZPT IBA $200 \mathrm{mg} /$ dan waktu perendaman 15 menit (A4W3).

Secara visual untuk seluruh perlakuan, umumnya akar muncul dari bagian bawah stek, akar yang dihasilkan kecil - kecil dan serabut Bentuk akar berupa silinder dan filament (panjang dan ramping). Perkembangan pertumbuhan akar untuk masing - masing interaksi perlakuan dapat dilihat pada Gambar 4.

Tabel 1. Pengaruh perlakuan ZPT IBA dan Waktu Perendaman Terhadap Jumlah Tunas, Tinggi Tunas dan Jumlah Daun

\begin{tabular}{rcccc}
\hline Perlakuan & & Jumlah Tunas & Tinggi Tunas (cm) & Jumlah Daun \\
\hline Dosis IBA & & & & \\
A1 & $0 \mathrm{mg} / 1$ & $1.963 \mathrm{a}$ & $1.659 \mathrm{a}$ & $2.665 \mathrm{a}$ \\
$\mathrm{A} 2$ & $50 \mathrm{mg} / 1$ & $1.759 \mathrm{a}$ & $1.493 \mathrm{ab}$ & $2.009 \mathrm{ab}$ \\
$\mathrm{A} 3$ & $100 \mathrm{mg} / 1$ & $1.870 \mathrm{a}$ & $1.020 \mathrm{~b}$ & $1.607 \mathrm{~b}$ \\
$\mathrm{~A} 4$ & $200 \mathrm{mg} / 1$ & $0.833 \mathrm{~b}$ & $1.006 \mathrm{~b}$ & $1.706 \mathrm{~b}$ \\
Waktu Perendaman & & & \\
W1 & 5 menit & th & $1.618 \mathrm{a}$ & 2.483 \\
W2 & 10 menit & th & $1.288 \mathrm{ab}$ & $2.258 \mathrm{a}$ \\
W3 & 15 menit & th & $0.978 \mathrm{~b}$ & $1.249 \mathrm{~b}$ \\
\hline
\end{tabular}

Keterangan : Angka - angka yang diikuti huruf yang sama tidak berbeda nyata berdasarkan uji DMRT pada taraf $5 \%$

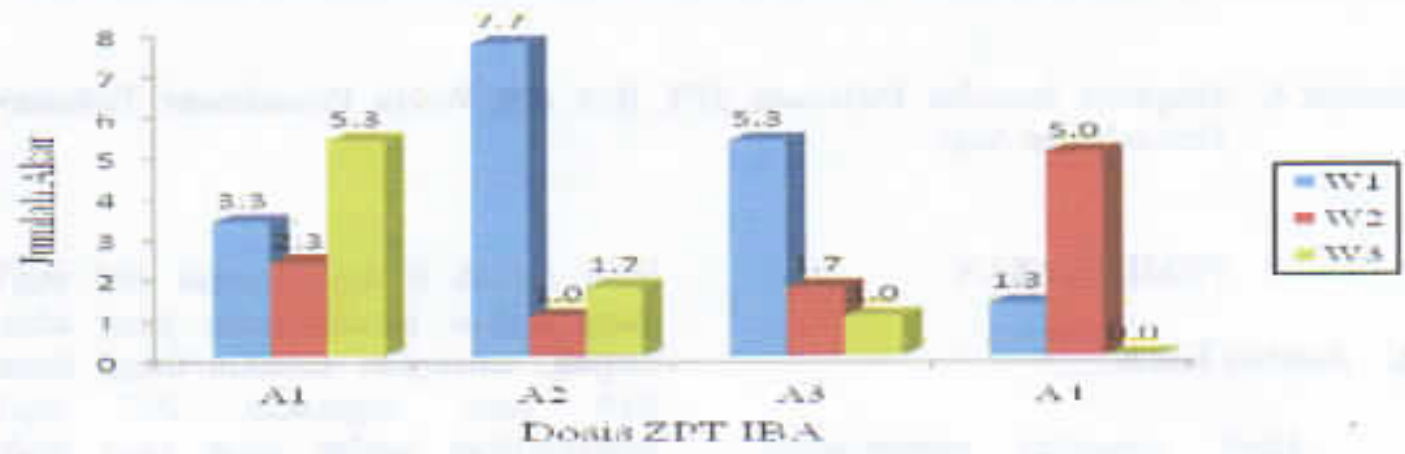

Gambar 3. Rata - rata Pertumbuhan Jumlah Akar 
Tabel 2. Pengaruh Interaksi Perlakuan ZPT IBA dan Waktu Perendaman Terhadap Parameter Pertumbuhan Bibit Tanaman Nanas

\begin{tabular}{|c|c|c|c|c|}
\hline $\begin{array}{l}\text { Interaksi } \\
\text { Perlakuan }\end{array}$ & Jumlah Tunas & $\begin{array}{l}\text { Tinggi Tunas } \\
\text { (cm) }\end{array}$ & Jumlah Daun & $\begin{array}{c}\text { Panjang Akar } \\
\text { (cm) }\end{array}$ \\
\hline AIW1 & $1.611 \mathrm{bcd}$ & $1.939 \mathrm{ab}$ & $3.417 \mathrm{a}$ & $5.100 \mathrm{~b}$ \\
\hline $\mathrm{A} 1 \mathrm{~W} 2$ & $1.889 \mathrm{abc}$ & $1.172 \mathrm{bed}$ & $2.089 \mathrm{abc}$ & $5.767 \mathrm{~b}$ \\
\hline AlW3 & $2.389 a b$ & $1.867 \mathrm{abc}$ & $2.489 a b$ & $8.900 \mathrm{ab}$ \\
\hline $\mathrm{A} 2 \mathrm{~W} 1$ & $2.667 a$ & $2.644 a$ & $3.367 \mathrm{a}$ & $18.967 \mathrm{a}$ \\
\hline $\mathrm{A} 2 \mathrm{~W} 2$ & $0.944 \mathrm{~d}$ & $0.844 \mathrm{~d}$ & 1.044 bed & $1.400 \mathrm{~b}$ \\
\hline $\mathrm{A} 2 \mathrm{~W} 3$ & $1.667 \mathrm{bcd}$ & $0.989 \mathrm{~cd}$ & $1.617 \mathrm{bc}$ & $4.067 \mathrm{~b}$ \\
\hline $\mathrm{A} 3 \mathrm{~W} 1$ & 2.278 abc & $0.933 \mathrm{~d}$ & $1.594 \mathrm{bc}$ & $9.600 \mathrm{ab}$ \\
\hline $\mathrm{A} 3 \mathrm{~W} 2$ & $1.889 \mathrm{abc}$ & $1.072 \mathrm{bed}$ & $2.339 \mathrm{abc}$ & $0.933 \mathrm{~b}$ \\
\hline$\Lambda 3 \mathrm{~W} 3$ & $1.444 \mathrm{~cd}$ & $1.056 \mathrm{bed}$ & 0.889 ed & $1.567 \mathrm{~b}$ \\
\hline $\mathrm{A} 4 \mathrm{~W} 1$ & $0.833 \mathrm{~d}$ & $0.956 \mathrm{~d}$ & $1.556 \mathrm{bc}$ & $2.000 \mathrm{~b}$ \\
\hline $\mathrm{A} 4 \mathrm{~W} 2$ & $1.667 \mathrm{bcd}$ & $2.061 \mathrm{a}$ & $3.561 \mathrm{a}$ & $11.533 \mathrm{ab}$ \\
\hline A4W3 & $0 \mathrm{e}$ & $0 \mathrm{e}$ & $0 \mathrm{~d}$ & $0 \mathrm{~b}$ \\
\hline
\end{tabular}

Keterangan : Angka - angka yang diikuti huruf yang sama tidak berbeda nyata berdasarkan uji DMRT pada taraf 5\%

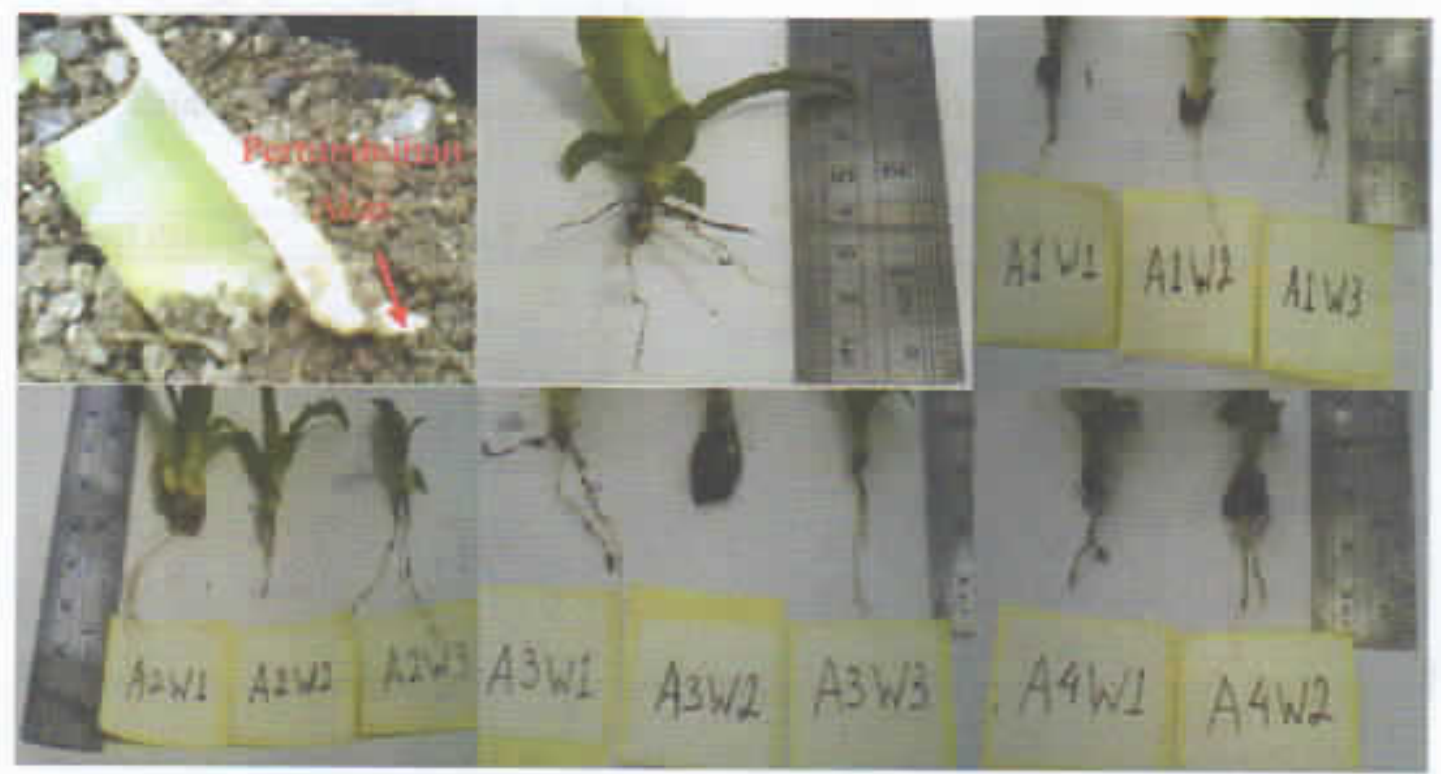

Gambar 4. Pengaruh Interaksi Perlakuan ZPT IBA dan Waktu Perendaman Terhadap Pertumbuhan Akar

PEMBAHASAN

\section{A. Jumlah Tunas}

Hasil penelitian menunjukkan bahwa penggunaan dosis ZPT IBA yang lebih rendah $0 \mathrm{mg} / \mathrm{s}$ sampai $100 \mathrm{mg} /$ menghasilkan jumlah tunas yang lebih banyak, sedangkan semakin tinggi dosis IBA yang digunakan $200 \mathrm{mg} /$ menghasilkan jumlah tunas yang lebih sedikit. Sesuai dengan fungsi dan 
kegunaannya, ZPT IBA merupakan senyawa yang dalam konsentrasi rendah dapat meraigsang peitumbuliait tain perkembangan tanaman terutama bagianbagian vegetatif dari tanaman, sedangkan konsentrasi IBA yang terlalu tinggi dapat menurunkan jumlah tunas (Heddy, 1986). Menurut Harjadi (2009), pemberian IBA pada konsentrasi tinggi dapat menyebabkan terjadinya penghambatan tunas pada tanaman mawar. IBA merupakan zat pengatur tumbuh dari golongan auksin yang menunjukkan efek penghambatan pertumbuhan tunas.

Untuk interaksi perlakuan menunjukkan bahwa perlakuan ZPT IBA $50 \mathrm{mg} / \mathrm{dan}$ waktu perendaman 5 menit (A2W1) memberikan respon pertumbuhan jumlah tunas yang paling baik yaitu sebesar 2,667. Ilasil ini scjalan dengan hasil penclitian Subhan (1998), dimana interaksi perlakuan konsentrasi IBA dan lama perendaman juga menunjukkan pengaruh yang nyata terhadap jumlah tunas pada stek tanaman anggur. Pembentukan turas sangat penting sebagai tahap awal primordia daun. Menurut Lakitan (2000), secara biologis tanaman yang sudah bertunas akan memiliki metabolisme yang baik, karena adanya tunas maka tanaman dapat menjaga kelembabannya dan meminimalkan stek yang mati akibat kekeringan, selain itu tumas dapat memproduksi hormon auksin alami.

\section{B. Tinggi Tanaman (Tinggi Tunas)}

Hasil penelitian penggunaan ZPT IBA $0 \mathrm{mg} /$ (kontrol) memberikan respon pertumbuhan tinggi tunas yang paling baik yaitu sebesar $1,659 \mathrm{~cm}$. Hal ini diduga bahwa auksin endogen (fitohormon) sudah mencukupi untuk meningkatkan tinggi tanaman (tinggi tunas).

Tanaman pada umumnya dapat mensintesis hormonnya sendiri. Auksin yang diberikan secara eksogen tidak mempengaruhi pembentukan tunas, karena pembentukan tunas lebih dipengaruhi oleh adanya sitokinin endogen. Selain itu pertumbuhan dan perkembangan tanaman dikontrol oleh adanya keseimbangan hormon dalam tanaman. Inisiasi dan pembentukan tunas dikontrol oleh adanya interahai antara auksin dan sitokinin. Perbandingan antara auksin dan sitokinin yang tepat akan meningkatkan pembelahan sel dan diferensiasi sel, salah satu responnya adalah penambahan tinggi tunas (Salisbury and Ross, 1995).

Hasil pengujian juga menunjukikan bahwa semakin tinggi dosis IBA yang diberikan, mengakibatkan pertumbuhan tinggi tunas yang lebih rendah. Hal ini sejalan dengan hasil penelitian lain pada eksplan kakao, dimana pemberian IBA pada konsentrasi rendah $500 \mathrm{ppm}$, menghasilkan tinggi tunas yang lebih besar dibandingkan dengan konsentrasi tinggi $3.000 \mathrm{ppm}$ (Alkindi, 2012). Menurut Mulyono (2010), penambahan konsentrasi IBA yang lcbih tinggi pada tanaman gaharu (Aquilaria beccariana) tidak menyebabkan penambahan tinggi planlet, tetapi ditranslokasikan ke bagian pangkal untuk pembentukan akar.

Untuk pengaruh lamanya waktu perendaman terhadap tinggi mas menunjukkan bahwa waktu perendaman yang lebih cepat yaitu 5 menit (W1) memberikan tinggi tunas yang paling baik yaitu sebesar $1.618 \mathrm{~cm}$. Sedangkan semakin lama waktu perendaman mengakibatkan rata-rata pertumbuhan tinggi tunas yang lebih rendah. $\mathrm{Hal}$ ini diduga bahwa waktu perendaman yang lebih cepat pada stek daun mahkota buah pada tanaman nanas sudah mampu mentranslokasilen ZTT IBA he bagian tanaman yaitu jaringan meristematik sehingga mampu meningkatkan tinggi tunas. Menurut Panjaitan (2000), tinggi rendahnya hasil dari penggunaan ZPT tergantung pada beberapa faktor, salah satu diantaranya adalah lamanya waktu perendaman stek dalam larutan.

Interaksi perlakuan ZPT IBA 50 mg/ dan waktu perendaman 5 menit (A2W1) memberikan respon pertumbuhan tinggi tunas yang paling baik yaitu sebesar $2.664 \mathrm{~cm}$. Hasil ini membuktikan bahwa dengan dosis IBA yang lebih rendah dan waktu perendaman yang lebih eepat sudah mampu mentranslokasikan ZPT IBA ke dalam jaringan tanaman nanas sehingga 
mampu meningkatkan tinggi tunas secara optimum.

Tanaman pada umumnya dapat mensistesis hormonnya sendiri yaitu auksin endogen (fitihormon) pada organ tertentu yang pada gilirannya berfungsi untuk merangsang terjadinya respon pada organ hain. Namun seringkali ketersediaan hormon secara alami ini di bawah optimal, schingga perlu ditambahkan hormon eksogen atau hormon sintetik seperti ZPT IBA. Penambahan ZPT IBA dengan dosis yang tepat dapat menghasilkan respon yang dikehendaki. Pemberian zat pengatur tumbuh dengan konsentrasi yang tinggi menyebablan altivitas pembelahan sel menjadi lambat, sehingga kecil pengaruhnya terhadap peningkatan pertumbuhan tanaman (Pamungkas, dkk . 2009).

\section{Jumlah Daun}

Hasil penelitian menunjukkan periakuan ZPT IBA 0 mg/l (A1) memberikan respon pertumbuhan jumlah daun yang paling baik yaitu 2.665. Hal ini diduga bahwa tampa perlakuan ZPT IBA, kandungan hormon sitokinin endogen pada stek daun mahkota buah nanas telah mampu memacu pertumbuhan tunas dan meningkatkan jumlah daunnya.

Sebagaimana yang terjadi pada pertambahan tinggi tunas, waktu perendaman yang lebih cepat yaitu 5 menit (W1) juga dapat menghasilkan rata-rata jumlah daun yang lebih banyak yaitu 2,483 . Hal ini membuktikan bahwa waktu perendaman yang eepat seiain dapat meningkatkan tinggi tunas juga mampu meningkatkan jumlah daun.

Interalssi perlakuan ZPT IBA 50 mg/ dan waltu perendaman 5 menit (A2W1) dengan perlakuan ZPT IBA 200 mg1 dan waktu perendaman 10 menit (A4W2) memberikan respon pertumbuhan jumlah daun yang tidak berbeda nyata. Hasil ini membuktikan bahwa dengan dosis IBA yang lebih rendah dan waktu perendaman yang lebih eqpat sudah mampu mentranslokasikan ZPT IBA ke dalam jaringan tanaman sehingga mampu meningkatkan jumlah daun secara optimum. Secara ekonomis perlakuan dosis ZPT IBA yang lebih rendah dan waktu perendaman yang eepat lebih menguntungkan.

Pembentukan tunas sangat penting sebagai tahap awal primordia daun, dimana daun merupakan organ tanaman yang memiliki jumlah klorofil terbesar dan berfungsi scbagai tempat terjadinya proses fotosintesis untuk menghasilkan energi bagi tanaman.

Tujuan pemberian hormon eksogen adalah agar senyawa-senyawa ini mampu mendorong inisiasi proses biokimia tanaman yang akhimya diharapkan dapat membentuk organ dan aspek tumbuh lainnya. Selain itu pemberian hormon juga berguna untuk merangsang pertumbuhan tunas, meningkatkan tinggi tunas dan menghasilkan pembentukan daun. Pembentukan daun ini berkorelasi positif terhadap proses fotosintesis untuk memproduksi nutrisi dengan memanfaatkan energi cahaya (Salisbury and Ross, 1995).

Sclain pengamatan terhadap pertumbuhan tunas, tinggi tunas dan jumlah daun, dilakukan pula pengamatan secara visualisasi terhadap pertumbuhan stek daun. Hasilnya sekitar $10 \%$ stek daun mahkota buah nanas mengalami pembusukan. Hal ini diduga akibat kelembabannya terlalu tinggi dikarenakan faktor penyiraman. Stek daun yang mengalami pembusukan dan kering (layu) harus dipotong dan dibuang untuk menghindari tumbuhnya jamur pada bibit tanaman nanas yang lainnya.

\section{Sistem perakaran}

Hasil penelitian menunjukkan bahwa interaksi perlakuan ZPT IBA 50 $\mathrm{mg} / 1$ dan lamanya waktu perendaman 5 menit (A2W1) menghasilkan rata-rata jumlah akar yang paling banyak dan memberikan pengaruh yang paling baik terhadap pertumbuhan panjang akar jika dibandingkan dengan interaksi perlatuan lainnya. $\mathrm{Hal}$ ini mengindikasikan bahwa pemberian ZPT IBA dengan dosis $50 \mathrm{mg} / 1$ dan waktu perendaman 5 merit ( $\mathrm{\Lambda} 2 \mathrm{~W} 1)$ 
dapat meningkatkan jumlah akar dan menunjang pertumbuhan panjang akar yang paling baik. Sedaughan tampa pemberian IBA maupun konsentrasi IBA yang terlalu tinggi dapat menurunkan jumlah dan panjang akar serta menyebabkan stek tidak berakar. ZPT IBA merupakan senyawa yang dalam konsentrasi rendah dapat merangsang pertumbuhan dan perkembangan bagian bagian vegetatif dari tanaman seperti akar (Heddy, 1986).

ZPT IBA efektif dalam menginduksi pembentukan akar pada berbagai spesies tanaman. Aplikasi IBA akan menghasilkan sistem perakaran yang kuat dan berserabut (Weaver, 1972). Menurut Ashari (1995) konsentrasi larutan IBA untuk stek berkisar antara $20 \mathrm{ppm}$ untnk stck yang mudah berakiar hingga beberapa ribu ppm untuk stek yang sukar berakar dan lama perendaman 30 menit hingga 24 jam. Tujuan pemberian ZPT IBA adalah agar senyawa - senyawa ini dapat mendorong inisiasi proses - proses biokimia tanaman, sehingga pemberian ZPT IBA mampu meningkatkan kualitas sistem perakaran baik jumlah akar maupun panjang akarnya. Penelitian pada tanaman jati (Tectona grandis L.) dengan pemberian homone IBA pada konsentrasi 200 ppm dapat mempercepat proses pembentukan akar, meningkatkan jumlah akar (Pujianto, et al 2010).

Secara visual untuk seluruh perlakuan, umumnya akar muncul dari bagian bawah stck, akar yang dihasilkan kecil - keeil dan serabut. Bentuk akar berupa silinder dan filament (panjang dan rampin). Bentuk akar seperti ini memberikan keuntungan dalam menyerap air dan unsur hara (Lakitan, 2000). Rochiman dan Harjadi (1973), menjelaskan proses perakaran diawali dengan pembelahan sel - sel meristem yang terletak di antara jaringan atau di luar jaringan pembuluh kemudian memanjang. selanjutnya membentuk lebih banyak sclsel yang akan berkembang menjadi akar. Pertumbuhan panjang akar seiring dengan kecepatan stek untuk berakar dan jumlah akar yang tumbuh. Menurut Heddy (1986), sistem perakaran yang baik akan mampu meningkatkan jumlah tunas, tinggi tunas dan jumlah daun tanaman.

\section{KESIMPULANDAN SARAN}

\section{Kesimpulan}

Penggunaan ZPT IBA sampai dosis $50 \mathrm{mg} / \mathrm{l}$ dapat meningkatkan pertumbuhan jumlah tunas, tinggi tunas dan jumlah daun bibit tanaman nanas Bogor asal stek mahkota buah. Sedangkan waktu perendaman selama 5 menit (W1) berpengaruh terhadap pertambahan tinggi tunas dan jumlah daunnya.

Interaksi perlakuan antara penggunaan ZPT IBA $50 \mathrm{mg} /$ dan lama waktu perendaman 5 menit (A2W1) merupakan interaksi perlakuan yang terbaik dalam menginduksi perakaran dan meningkatkan pertumbuhan bibit tanaman nanas Bogor asal stek daun mahkota buah.

\section{Saran}

Untuk menginduksi perakaran bibit tanaman nanas Bogor asal stek daun mahkota buah sebaiknya digunakan interaksi perlakuan ZPT IBA $50 \mathrm{mg} /$ dan waktu perendaman 5 menit (A2W1).

\section{UCAPAN TERIMA KASIH}

Penulis mengueapkan terima kasih dan penghargaan kepada DP2M DIKTI, yang berkenan memberikan dana penclitian Dosen Pemula Scsuai dengan Surat Perjanjian Pelaksanaan Hibah Penelitian No. 2497/K4/KL/2012 tanggal 6 Juli 2012 Ueapan yang sama juga disampaikan kepada Bapak Dr. Barijadi Prawirosastro., Ir. MS, selaku Rektor Universitas Nusa Bangsa, Bapak $H$. Agustono., Ir. MS selaku Ketua LP2M UNB, Bapak Dr. H. Pasril Wahid., Ir. MS. APU selaku Dekan Fakultas Pertanian UNB serta semua pihak yang telah membantu dalam pelaksanaan penelitian ini. 


\section{DAFTAR PUSTAKA}

Alkindi. 2012. Studi Pembiakan Vegetatif Pucuk Kakao (Theobroma casao L.) Menggunakan IBA Melalui Teknik Ex-Vitro. Skripsi. Fakultas Pertanian Universitas Nusa Bangsa (Tidak dipublikasikan).

Al-Saif, A. M., A. S Hossain and R. M. Taha .2011. Effects of Benzylammopurine And Naphthalene Acetic Acid On Proliferation And Shoat Growth of Pineapple Ananas comosus L Merr) $m$ viro. Afriean joumal of Biotechnology Vol. 10(27), pp. 5291 - 5295 .

Anwar, N. 2007. Penganuh Media Multiplikast Terhadap Pembentukan Akar Pada Tunas in Vitro Nenas LAnanas comusus L. Merr.) cv. Smotth Cayenne di Media Pengakaran. Skripsi. PS Pemuliaan dan Teknologi Benih. Fakiltas Pertanian IPR.

Ashari, S. 1995. Hortikulnura Aspek Budidaya. Universitas Indonesia Jakarta.

Budiman A. 2000. Pengaruh Hormon IBA Terhadap Pertumbuhan Stek Shorea balangeran Korth. Pada Meditum Air (Water Rooting System). Karya Ilmiah Jurusan Manajemen Hutan. IPB Bogor.

Harjadi, S. S. 2009. Zat Pengatur Tumbuh. Cet I. Pencbar Swadaya Jakarta.

Heddy, S. 1986. Hormon Tumbuhan. PT. Raja Grafindo Persada. Jakarta.

Karmanah. 1996. Penganih Indole Butyric Acid Terhadap Perakaran dan Pernumbuhan Bibit, serta Daya Adaptasi Lapang Tanaman Kelapa Asal Pembibitan Ganting. Skripsi. Fakultas Pertanian Universitas Nusa Bangsa (Tidak dipublikasikan).
Lakitan, B. 2000. Dasar-dasar Fisiologi Tumbuhan. PT. Raja Grafindo Persada. Jakarta.

Mattjik, A. N dan M. Sumertajaya. 2000. Perancangan Percobaan dengan Aplikasi SAS dan Minitab. IPB Press. 326 p.

Mnlyono, D. 2010. Pengaruh Zat Pengathr Tumbuh Auksin : Indole Butyric Acid (IBA) dan Sitokinin; Benzile Amino Purin (BAP dan Kinentin dalam Elongasi Pertunasan Gaharu (Acnillaria beccariana) Jumal Sains dan Teknologi Indonesia 12 (1) $: 1-7$.

Pamungkas, F. T., S. Darmanti dan B. Raharjo. 2009. Pengarwh Konsentrasi dan Lama Perendaman dalam Supernatan Kultur Bacillus sp. 2 ducc-br-k1.3 Terhadap Pertumbuhan Stek Horisontal Batang Jarak Pagar (Jatropha carcas L.). J. Sains \& Mat. Vol. 17 No. $3: 131140$.

Panjaitan, M. 2000. Pengaruh Konsentrasi IBA dan Lama Perendaman Terhadap Presentase Keberhasilan Pertumbuhan Stek Pucuk Jenuk Nipis. Skripsi. Fakiultas Pertanian. Universitas Katolik Santo Thomas Sumatera Utara. Medan.

Pujianto, A dan Karmanah. 2010. Respon Pertumbuhan Stek Puctuk Jati (Tectona grandis L.f. Terhadap Beberapa Kosentrasi Hormon IBA dan Jenis Media Pembibitan. Jurnal Nusa Tani Volume 10 No. 1. Juni 2010.

Rochiman, K dan S. S Harjadi 1973. Bahan Bacaan Pengantar Agronomi : Pembiakan Vegetatif. Fakultas Pertanian IPB. Bogor.

Salisbury, F. B and C. W. Ross. 1995. Fisiologi Tumbuhan Ed $\mathrm{Ke}-4$. Lukman \& Sumaryono, penerjemah. Penerbit ITB. 
Soedarya, A. P. 2009. Agtbisnis Nanas. CV. Pustaka Gafika. Bandung.

Setiawan, E dan Karmanah. 2010. Penganih Kamposisi Media Tanam Dan Pemberian Dosis Pupuk Kandang Terhadap Pertumbuhan Bibit Dari Mahkota Buah Nanas (Ananas comosus L. Merr). Jurnal Nusa Tani Volume 10 No 2. Desember 2010.

Subhan, M. 1998. Pengaruh Konsentrasi IBA dan Lama Perendaman Terhadap Pertumbuhan Stek Tanaman Anggur Vitis vinifera. Linn) Kultivar Kining Kediri Bersemi. Skripsi. Fakultas Pertanian Universitas Nusa Bangsa (Tidak dipublikasikan).
Sukawan, I. K. C. 2000. Perbanyakan Tanaman Nanas Varietas Variegata (Ananas comusus "Variegatus") Secara In Vitro. Skripsi. Junısan Budidaya Pertanian Fakultas Pertanian. IPB Bogor.

Wattimena G. A. 1987. Diktat Zat Pengatur Tumbuh Tanaman. Direktorat Jenderal Pendidikan Tinggi. Departemen Pendidikan dan Kebudayaan.

Weaver, JR. 1972. Plant Growth Subtances in Agriculture, W. H. Freeman and Company. San Fransisco, $126-150$ p. 